УДК $811.111 .81^{\prime} 42$

DOI https://doi.org/10.26661/2414-1135-2021-82-25

\title{
ЛІНГВІСТИЧНІ ОСОБЛИВОСТІ ЕТНОКУЛЬТУРНОГО АСПЕКТУ В СУЧАСНІЙ АНГЛІЙСЬКІЙ МОВІ
}

\author{
Матковська М. В. \\ доиент кафедри англійської мови \\ Кам'янеиь-Подільський наџіональний університет імені Івана Огієнка \\ вул. Огієнка, 61, Кам'янець-Подільський, Хмельнищька область, Украӥна \\ orcid.org/0000-0002-1047-7027 \\ matkovska.mariya@kpnu.edu.ua
}

\begin{abstract}
Ключові слова: культура, національний характер, ментальність, етнічні стереотипи, етнономінація, етнонім.
\end{abstract}

У статті на матеріалі трилогії Томаса Стоппарда «Острів Утопії» визначено основні фрагменти англомовної картини світу, представленої лінгвістичними особливостями етнокультурного аспекту в мовній об'єктивації російського етносу британською лінгвокультурною спільністю. Увагу зосереджено на спробі дослідження етнічних стереотипів, які існують у пізнанні людиною навколишнього світу іншого народу, є етнономінаціями та створюють своєрідний етнокультурний образ багатонаціонального світу, що впливає на організацію міжетнічної комунікації: на вибір відповідних номінативних одиниць та стратегічне розгортання спілкування. Дослідження та сприйняття іншої культури завжди проходить крізь призму своїх національних цінностей та властивостей характеру, відповідно, сприймання росіян, зокрема, англійцями дає багатий матеріал для вивчення англійського менталітету. Автор аналізує стереотипні уявлення англійців про національний характер та особливості національного менталітету російської етнічної спільноти. Виявляється, що росіянам потрібен сильний жорсткий лідер, оскільки вони звикли до беззастережливого підпорядкування владі та авторитету. У результаті аналізу виявлено, що позитивна оцінка факту, дії або явища надає об’ єкту, що описується, характеристик «свого»: за норму, ідеал, щось позитивне сприймаються суспільством лише свої культурні надбання. Те, що оцінюється негативно, належить до класу «чужого». Таким чином, все, що оцінюється позитивно, є характеристикою «свого» та береться за правило; все, що оцінюється негативно, описується як чуже і тому зазнає відторгнення. Саме екстралінгвістичні фактори (політична, соціально-економічна ситуація) визначають, якої форми набуде контакт двох націй: діалогу чи конфлікту.

Постулюється ідея, що домінантні риси національного характеру представників інших культур складаються в англійців у певний стереотип, який $є$ стійким утворенням та таким, що не завжди відповідає дійсному стану речей. У ситуаціях міжетнічного спілкування процес комунікації відбувається на основі стратегій ототожнення та дистанціювання. Відповідні стратегії в міжетнічній взаємодії визначають спрямування комунікативних дій мовців із можливим наданням експліцитної або імпліцитної оцінки чи характеристики. 


\title{
LINGUISTIC PECULIARITIES OF THE ETHNOCULTURAL ASPECT IN MODERN ENGLISH
}

\author{
Matkovska M. V. \\ Associate Professor at the English Language Department \\ Kamianets-Podilskyi Ivan Ohiienko National University \\ Ohiyenko str., 61, Kamyanets-Podilskiy, Khmelnytsky region, Ukraine \\ orcid.org/0000-0002-1047-7027 \\ matkovska.mariya@kpnu.edu.ua
}

Key words: culture, national character, mentality, ethnic stereotypes, ethnonomination, ethnonim.
This paper is devoted to the main fragments of the English-speaking representation of the world, being presented by linguistic peculiarities of the ethnocultural aspect in language objectification of the Russian ethnos by the British linguocultural community. Attention is focused on the attempt to investigate ethnic stereotypes that exist in people's cognition of the world of another nation; they appear to be ethnonominations and create the specific ethnocultural image of the multinational world that influence the organization of interethnic communication: the choice of appropriate nominative units and strategic deployment of communication. The research and perception of another culture are always depicted through the prism of national values and character's peculiarities, accordingly, the perception of the Russians, in particular, by the English supplies with the rich data for studying the English mentality.

The author examines the stereotyped conception of the English about the national character and the peculiarities of the national mentality of the Russian ethnic community. The Russians are supposed to need a strong and strict leader as they have been used to following the idea of unprecedented submission to the authorities. The result asserts the fact that the positive assessment of facts, actions, or phenomena grants the object being depicted the characteristics of "own". These are norms; ideals, and something positive that have been perceived by the society as "own" cultural values. The notions, being estimated negatively are treated as "alien" ones. Thus positive assessment is the characteristic of "own" and is taken for granted. The negative assessment is treated as "alien" and that is why undergoes some rejection. The very extralinguistic factors (political, social, and economic) determine the form of the communication of two nations: whether it is the form of a dialogue or a conflict. It is postulated the idea that the dominant features of national characters of the representatives of other cultures are turned out by the English into definite stereotypes that are stable formations not always correspond to the true state. In the situations of interethnic relations, the process of communication is being conducted based on identification and distancing strategies. These strategies regulate communicative actions of speakers with the possible assignment of explicit or implicit appraisal or description.
Постановка проблеми. Уявлення людини про навколишню об'єктивну реальність та спосіб, яким вона класифікує світ, виражаються в його мові; $з$ іншої сторони, мова - це єдиний засіб, який допоможе нам проникнути у приховану від нас сферу ментальності, бо вона детермінує спосіб поділу світу в тій чи іншій культурі. Останнім часом дедалі складнішою стає ситуація в міжнародних, міжетнічних відносинах, оскільки мовою відображається національна ментальність, виявляються актуальними дослідження в галузі мови як основного виразника уявлень про світ, а в окре- мих випадках і про інший народ. Знання такого типу дають змогу побачити себе, свою країну та співвітчизників очима іншої нації, передбачити більшість конфліктних ситуацій у відносинах двох націй і деякою мірою попередити їх.

Важливим для сучасної лінгвістики є також встановлення ролі окремих номінативних одиниць у забезпеченні процесу спілкування. У сучасному мовознавстві дедалі більше зростає інтерес до дослідження людського фактора в пізнанні мови [1, с. 25-27], оскільки воно потребує виходу за межі власне мови, зі зверненням до 
людини, однією із суттєвих характеристик якої є етнічна ідентичність, а моделювання мовної картини світу є одним із актуальних напрямів.

Аналіз останніх досліджень і публікацій. Значна традиція дослідження мови, мислення та процесів пізнання взагалі і мови зокрема відображається в лінгвістичних працях В. Гумбольдта, Л. Сльмслєва, І.О. Бодуена де Куртене, Г. Гійома. Через мову ми отримуємо знання про світ, і саме через мову ми виражаємо ці знання [2, с. 115-117]. Етнокультурні аспекти національних характерів зображені в працях вітчизняних та зарубіжних лінгвістів (А. Вежбицька, А.С. Герд, Г. Гійом, В.І. Карасик, I.М. Кобозєва, В.І. Кононенко, В.В. Красних, P. Brown, S. Levinson, D. Crystal, C. Kramsch, S. Levinson, A. Wierzbicka). Мова виступає як спосіб відображення навколишнього світу й мисленнєвої діяльності різних етнічних спільнот. Остання ж нерозривно пов'язана 3 практичною діяльністю людини. Здатність відображення $€$ властивістю мозку, а не мови, тому про вторинну картину світу можна говорити, лише маючи на увазі мислення. Відповідно, мова виступає вторинною формою існування мислення [3, с. 127].

Орієнтація слова на узагальнення є однією з універсалій мови. Проте слово узагальнює настільки, наскільки це узагальнення вже відбулося в процесі психічного відображення дійсності до виникнення матеріальної оболонки. Створено багато моделей, за допомогою яких робляться спроби пояснити, як пересічний мовець розуміє та класифікує світ, як він використовує в мові весь свій життєвий досвід і накопичує знання [4, с. 113].

Метою статті $€$ аналіз лінгвістичних особливостей етнічних стереотипів та етнономінацій, які формують своєрідний етнокультурний образ багатонаціонального світу, на матеріалі трилогії Томаса Cmonnарда «Oстрів Утопї̈».

Виклад основного матеріалу. У межах когнітивної парадигми мовні форми вивчаються не самі собою, автономно, а $з$ позицій того, як вони презентують певне бачення світу людиною та способи його концептуалізації в мові, загальні принципи категоризації та механізми обробки інформації. Мова за такого підходу виступає як знаряддя пізнання та концептуалізації людиною навколишнього середовища і самої себе.

Процес пізнання дійсності нерозривно пов'язаний із мовою. Мова виступає лише як частина того цілісного явища, яке ми намагаємося пізнати i має описуватись як інтегральний аспект усієї психічної діяльності людини.

Вербальні одиниці $є$ продуктом складного процесу усвідомлення оточуючої дійсності. Опосередковано через мовні одиниці індивід інтегрує фрагмент реального світу у свою ментальну реальність. Таким чином, мова $є$ основним засо- бом вираження думки, а вивчення мови - це опосередковане вивчення пізнання [5, с. 129-134].

Спостереження за мовою як формою відображення та вираження процесів мислення надає найкращий доступ до свідомості людини. Поведінка людини визначається структурами знання, які в неї $є$, і тим, як вона зображує світ. Водночас людина не показує світ поза мовою [3, с. 145].

Когнітивний підхід до проблеми мови та мислення, на відміну від традиційного, робить акцент на особливій ролі людського фактора в пізнавальному та мовленнєво-мисленнєвому процесах i, відповідно, не тільки на колективному, а й на індивідуальному знанні окремих мовців, на його ролі у формуванні смислу висловлювання та значення окремих мовних одиниць [3, с. 154].

Антропоцентричний підхід до мови орієнтований, головним чином, на людину в іiі ставленні до мови та відображеної нею дійсності. Центральним фактором, що визначає специфіку того чи іншого кола явищ, є людина. Поза людиною мову вивчати не можна. Усі дослідницькі координати мають перехрешуватися на людині. Якщо мова - це дзеркало людського духу, то відбивається в ньому перш за все людська особистість, концепт якої входить до переліку констант культури. Людина бере активну участь у виборі мовних засобів виразу для опису тієї чи іншої ситуації та в розумінні мотивів цього вибору [2, с. 175-177; 3, с. 121-124].

Сучасна лінгвістика стала істотно орієнтуватися на вивчення концептуальних систем національних мов. Мова використовується як ключ до системи мислення та природи людської психіки. На основі мовних даних ми відтворюємо певні процеси мислення. Таким чином, мова стає не метою, а засобом проведення лінгвістичних досліджень. Вивчення мовних форм неповне без звернення до когнітивних категорій, оскільки категорії мислення практично невіддільні від мовних категорій [4, с. 111].

Результатом пізнання світу $\epsilon$ інтерпретація мовними засобами, позначення й утримання у свідомості його властивостей у вигляді певної сітки понять, тобто концептуальна картина світу. Остання формується свідомістю людини та дає змогу ефективно орієнтуватися у світі, використовувати його у своїх цілях. Концептуальна картина як сукупність знань людини про світ експлікується в мовній картині світу.

Картина світу існує у двох основних формах концептуальній та знаковій. Знання людини про світ бідніші за сам світ. Своєю чергою мова бідніша за наші знання. Обмеженість можливостей мови закономірна й природна, оскільки надмірність змісту веде до економії форми, але водночас це дозволяє виразити необмежені обсяги змісту. Концептуальна картина багатогранніша за мовну 
картину світу, оскільки в ії творенні беруть участь різні ментальні простори.

Мова є знаковою системою, і різні типи знаків як члени єдиної репрезентативної системи представляють певні аспекти концептуальної картини світу, тобто знання про світ. Це знання є складовою частиною значення одиниць, які утворюють власне систему мови - лексикон та граматику [3, с. 231]. У мові, в її лексичних та граматичних значеннях, у тому чи іншому ступені фіксуються результати людського пізнання [3, с. 242]. Семантика мовних та мовленнєвих одиниць не є довільною, а зображує основні категорії і структури наших моделей пізнання дійсності.

Як відомо, міжлюдське спілкування не зводиться лише до обміну інформацією. Чим більше збігаються моделі світу співрозмовників, тим глибше таке проникнення, тим скоріше й легше досягається узгодження поглядів. Значну роль у цьому відіграють стереотипи, які регулюють процес спілкування. Поняття стереотипу останнім часом широко вживається в культурології, етнології, соціології, психології, літературознавстві, мовознавстві, отримавши при цьому різне трактування [6, с. 68-69].

У когнітивній лінгвістиці та етнолінгвістиці термін «стереотип» стосується виключно змістовної частини мови та культури, тобто розуміється як ментальний стереотип, і корелює 3 картиною світу $[4$, с. $173-175]$.

Із соціально-психологічного погляду стереотипи виступають загальними когнітивними схемами, що спрямовані на осягнення соціальної дійсності.

Стереотипи виступають у ролі збірного, узагальненого уявлення про явище, яке є предметом обговорення та сприяють встановленню взаєморозуміння між співрозмовниками. Прикладами таких інваріантів образу світу можуть бути етнокультурний та професійний образ світу [4, с. 221].

Реконструкція стереотипів свідомості комунікантів є необхідною ланкою в аналізі процесів розуміння та породження мовлення. 3 усього розмаїття етнічних стереотипів виділяємо стереотипи сприймання, тобто спрощені, схематизовані, емоційно забарвлені та стійкі образи будь-якої етнічної групи чи спільноти, що поширюються на всіх її членів. Етнічні стереотипи сприяють формуванню уявлень про різні народи та етноси [7, с. 105].

У лінгвістичних i соціально-психологічних концепціях стереотип трактується як форма оброблення інформації та стану знання [4, с. 288-289]. Стереотип, що являє собою фрагмент концептуальної картини світу, існує у свідомості як стійке, мінімізовано-інваріантне, зумовлене національно-культурною специфікою уявлення про предмет чи ситуацію. Стереотип є найвищим рівнем диференціації кодів, оскільки використовується для характеристик мовних колективів як їх символ. Образливі позначення іноземців $є$ не що інше, як згустки реальних або уявних якостей, які приписуються тій чи іншій соціальній спільноті [7, с. 115].

В основі стереотипу лежить реальний психологічний феномен. Останній є одним із компонентів установки сприймання, яка несе як попередній досвід індивіда, так і культурно-історичний досвід соціуму. Стереотипи свідомості, закодовані в структурі мови, виявляються в процесі їі вживання, самими носіями мови можуть не усвідомлюватися і навіть суперечити їхнім усвідомлюваним розумовим установкам, сформованим під впливом виховання та освіти [4, с. 225]. У міжособистісному спілкуванні значення, як «верхівка айсбергу» стереотипів, актуалізується асоціативними зв'язками до свідомих уявлень із відповідними словесними уявленнями. Ключем для викриття стереотипів національних характерів можуть служити лексичні конотації, які ми, слідом за Ю.Д. Апресяном, розуміємо як не суттєві, але стійкі ознаки поняття, що виражається лексемою та втілюють загальноприйняту в суспільстві оцінку відповідного предмета [8, с. 67].

Таким чином, завдання виявлення стереотипів національних характерів зводиться до виявлення конотацій в етнонімах, а точніше, тих несуттєвих семантичних ознак, які несуть інформацію про риси характеру [1, с. 115]. Поява певних конотацій в етнонімах залежить від позамовних факторів: історичних, політичних, релігійних контекстів існування цих лексичних одиниць і народів-референтів, а також від закономірностей міжкультурного спілкування.

Етнономінація як родове, загальне поняття має специфічний зміст. Якщо розглядати буквальне значення, то цей термін може позначати лише визначений етнос, наприклад: Russians [9, p. 942], French [9, p. 563], Poles [9, p. 942], Czechs [9, p. 240]. Сучасні назви етнонімічного характеру, як правило, позначають наднаціональні, етнічно змішані, адміністративно-політичні людські спільноти, наприклад: British [9, p. 167] та Englishmen [9, p. 425] (Angles, Welsh [9, p. 148-997], Scots [9, p. 1269], Irish [9, p. 752]). Термін етнонім застосовується також стосовно суперетнічних єдностей, таких як Slavs [9, p. 1243], Celts [9, p. 191], Germans [9, p. 940], Romans [9, p. 1232], чи етнополітичних організмів, які складаються 3 різних національних спільнот, наприклад: Americans [9, p. 118], Belgians [9, p. 940], Indians [9, p. 721], Hungarians [9, p. 941], Swedes [9, p. 942].

Етнономінації поділяються на макроетноніми та мікроетноніми. Макроетноніми охоплюють генетично неоднорідні великі етноси, наприклад: Russians, Americans, Afro-Americans. Мікро- 
етноніми застосовуються до спільнот, члени яких $\epsilon$ представниками єдиного племені, народності, нації, народу, етносу. Важливим є спостереження щодо виявлення опозиції макро- / мікро- у формуванні етнічних прізвиськ: у сфері неофіційних, образливих етнічних назв значно переважають пейоративні позначення жителів цілих держав, політичних союзів, рас безвідносно до їхньої дійсної етнічної ідентичності.

Існування таких макроетнонімів-прізвиськ, як Yank [10, p. 1478], yankee-doodle [10, p. 1478] американці, ricer, dink [10, p. 113] - представники східних рас, Sovs [9, р. 1381], сотmо [9, р. 269], Ivan $[10$, p. 392] - росіяни та громадяни колишнього Радянського Союзу безвідносно до їхньої дійсної національної приналежності, можна пояснити, виходячи 3 когнітивних особливостей сприйняття в процесі створення наївної картини світу (етноніми-прізвиська в жодному разі не несуть наукового знання та уявлення щодо відповідних етнічних груп).

Мовець, застосовуючи пейоративні номінації та наділяючи інші народи певними якостями, сприймає ситуацію міжетнічного спілкування глобально, нерозчленовано і не розрізняє, не класифікує «чужих» як представників визначеної національності з усіма властивими ознаками. Оцінювальна конотація етнонімів та назв етнонімічного характеру (етнонімів-прізвиськ, етнофобізмів) може стати однією з причин порушення або ускладнення міжкультурної комунікації.

Вивчення етнономінацій, закономірностей їх виникнення, розвитку та вживання неможливо відокремити від вивчення самих етносів, що сприяє розумінню тих складних процесів, які у своїй сукупності визначають етногенез та етнічну історію будь-якої людської спільноти. Самоназивання як вираження самосвідомості та називання іншими - стереотипізоване усвідомлення ззовні - є однією 3 найважливіших ознак певної етнічної єдності. Стійкість самого етносу загалом як соціальної системи виступає умовою порівняної стабільності зображення його у свідомості та самосвідомості. Етнономінації (авто- та зовнішні етноніми, етнофобізми й етноніми-прізвиська) несуть певні структури знання, що можуть стати у пригоді в процесі вивчення та оптимізації міжетнічної комунікації.

Ототожнення причин стосовно використання стереотипних номінацій щодо представників інших культур та спільнот сприятиме подоланню кризових процесів та уникненню непорозуміння в міжетнічних стосунках. Етнономінації, крім визначених етносів, як правило, позначають наднаціональні, етнічно змішані, адміністративно-політичні спільноти, що пояснюється сучасним членуванням багатонаціонального світу.
Стереотипи національних характерів можуть зазнавати змін та, як наслідок, не відповідати дійсному стану речей у визначений історичний період. Але, як свідчать дослідження у сфері міжкультурної комунікації, стереотипи є стійкими утвореннями, які трансформуються дуже повільно.

При етнічній номінації в сучасній англійській мові присутнє ототожнення або відчуження себе мовцем щодо певної етнічної спільноти. Вживаючи етноніми Englishman - англієць, Irishman - ірландець, Welshman - валлієць, Scotsman - шотландець, мовець ототожнює себе 3 відповідним етносом. Концепти формуються у свідомості людини 3 ii безпосереднього життєвого досвіду - сприйняття дійсності органами чуттів, із іiі предметної діяльності, 3 мисленнєвих операцій людини 3 іншими уже наявними в іiі свідомості концептами, що приводить до виникнення нових концептів, а також із мовного спілкування [11, с. 228].

У складі стійких словосполучень, що відбивають реалії суспільного та культурного життя тієї або іншої спільноти, етноніми уточнюють, модифікують значення основного компонента, викликають його переосмислення. Зазначені одиниці вторинної номінації 3 етнонімами позначають різноманітні предмети, явища, культурно зумовлений вид діяльності. Наприклад, Russian phenomenon - intellectual opposition [12, p. 141]; Yes - one! The intelligentsia! - Russian debut in lexicon [12, p. 141], Kukolnik is synonymous with the Russian theatre [12, p. 74]. Russians - limited progress in transcending the objective reality [12, p. 16]; Do you think there is something Russian about taking everything to extremes [12, p. 179].

Носій мови у виборі значення слова керується певними стереотипами. Етнічний стереотип $є$ фрагментом концептуальної картини світу, що існує у свідомості, й зумовлений національно-культурною специфікою уявлення про іноземців. Саме тому, на нашу думку, стереотипи міжетнічного спілкування займають чільне місце в комунікативно-пізнавальній діяльності особистості.

Висновки і пропозиції. У процесі нашого дослідження було розглянуто етнічні стереотипи, які виконують когнітивну, оцінну, соціальну функції та визначають поведінку індивіда, притаманні йому процеси сприймання та спілкування.

У сучасній англійській мові на позначення росіянина-іноземця існують як офіційні, нейтральні етнономінації, так і неофіційні етнонімічні назви. Перші утворюють групу загальновизнаних етнономінацій (офіційних етнонімів), які позбавлені позитивних або негативних конотацій i можуть набувати оцінного значення лише в мовленні для вираження прагматичної настанови адресанта.

Виявлено, що для номінації та надання характеристик представників російської етнічної 
спільноти в сучасній англійській мові характерним є концептуальне об'єднання типових фреймів етнічної номінації, які представляють інтегративні моделі різного рівня складності. Типовим є поєднання предметно-центричного фрейму з асоціативним фреймом етнічної номінації. У складі стійких словосполучень, що показують реалії суспільного та культурного життя тієї або іншої спільноти, етноніми уточнюють, модифікують значення основного компонента, викликають його переосмислення. Зазначені одиниці вторинної номінації з етнонімами позначають різноманітні предмети, явища, культурно зумовлений вид діяльності.

Перспективними в цій галузі можуть бути дослідження, орієнтовані на вивчення характерних стереотипів інших національних характерів, що займають чільне місце в комунікативно-пізнавальній діяльності особистості та в міжетнічному спілкуванні.

\section{ЛІТЕРАТУРА}

1. Вежбицкая А. Понимание культур через посредство ключевых слов. Москва : Языки славянской культуры, 2001. 288 с.

2. Гийом Г. Принципы теоретической лингвистики : монография. Москва : Прогресс, 1992. $224 \mathrm{c}$.

3. Вежбицкая А. Язык. Культура. Познание : монография. Москва : Русские словари, 1996. $416 \mathrm{c}$.

4. Герд А.С. Введение в этнолингвистику. Санкт-Петербург : Изд-во С.-Петерб. ун-та, 2001. $488 \mathrm{c}$

5. Карасик В.И. Языковой круг: личность, концепты, дискурс. Волгоград : Перемена, 2002. $447 \mathrm{c}$.

6. Kramsch C. Cultural Stereotypes. Language and Culture. Oxford : Oxford University Press, 1998. P. 67-69.

7. Кобозева И.М. Немец, француз и русский: выявление стереотипов национальных характеров через анализ коннотаций этнонимов. Вестник Моск. ун-та. Серия 9. Филология. 1995. № 3. C. 102-116.

8. Апресян Ю.Д. Лексическая семантика. Москва : Наука, 1974. 367 с.

9. Cambridge International Dictionary of English. Cambridge : Cambridge University Press, 1995. $1774 \mathrm{p}$.
10. Longman Dictionary of English Language and Culture. London : Longman, 1992. 1528 p.

11. Wierzbicka A. Understanding cultures through their key words: English, Russian, Polish, German, and Japanese. New York, Oxford : Oxford University Press, 1997. 328 p.

12. Stoppard T. The Coast of Utopia. A Trilogy: Voyage, Shipwreck, Salvage. New York : Grove Press, 2007. 347 p.

\section{REFERENCES}

1. Wezhbyczkaya, A. (2001). Understanding Cultures through their Key Words [Ponimaniye kultur cherez posredstvo klyuchevykh slov]. Moskva : Yazyki slavyanskoj kultury.

2. Gyjom, G. (1992). Principles of theoretical linguistics [Pryncipy teoreticheskoj lingvistiky]. Moskva : Progress.

3. Wezhbyczkaya, A. (1996). Language. Culture. Cognition [Yazyk. Kultura. Poznaniye]. Moskva : Russkye slovary.

4. Gerd, A.S. (2001). An Introduction to Ethnolinguistics [Vvedyeniye $\mathrm{v}$ etnolingvistiku]. SPb. : Izd-vo S-Peterb. un-ta.

5. Karasyk, V.E. (2002). Language circle: personality, concepts, discourse [Yazykovoj krug: lichnost, konsepty, diskours]. Volgograd : Peremena.

6. Kramsch, C. (1998). Cultural Stereotypes. Language and Culture. Oxford : Oxford University Press. P. 67-69.

7. Kobozeva, Y.M. (1995). The German, the French and the Russian: the identification of national stereotyped characters through the analysis of etnonyms connotations [Nemecz, franczuz y russkyj: vyyavlenye stereotypov nacyonalnyux kharakterov cherez analyz konnotacyj etnonymov]. Vestnyk Mosk. un-ta, Fylologyya, 9(3), 102-116.

8. Apresyan, Y.D. (1974). Lexical Semantics [Leksicheskaya semantika]. Moskva : Nauka.

9. Cambridge International Dictionary of English. (1995). Cambridge : Cambridge University Press.

10. Longman Dictionary of English Language and Culture. (1992). London : Longman.

11. Wierzbicka, A. (1997). Understanding cultures through their key words: English, Russian, Polish, German, and Japanese. New York, Oxford : Oxford University Press.

12. Stoppard, T. (2007). The Coast of Utopia. A Trilogy: Voyage, Shipwreck, Salvage. New York : Grove Press. 